\title{
ASPEK HUKUM FATWA MAJELIS PERMUSYAWARATAN ULAMA (MPU) TENTANG ALIRAN SESAT
}

\author{
Kurniawan \\ Fakultas Hukum Universitas Syiah Kuala Aceh \\ E-mail: kurniawanfh@yahoo.com
}

\begin{abstract}
This study is aimed at describing constitutional and legal basis of MPU in Aceh, describing the history of existence of the Ulama's roles in Aceh and also analyzing legal aspect and legal implication of deciding MPU Aceh concerning cult. The approaches used on this study are statute approach, cases approach, and historical approach. The result of analysis shows that fatwa issued by MPU Aceh concerning cult to several chairpersons of Islamic school (Pasantren/Dayah) in Aceh is against the law, especially Article 5 (b) Qanun Aceh No. 2 of 2009 on Aceh's Ulama Consultative Assembly.
\end{abstract}

Keywords: fatwa, Aceh's Ulama Consultative Assembly, cult

\begin{abstract}
Abstrak
Tulisan ini bertujuan untuk menjelaskan landasan hukum dan landaan konstitusional Majelis Permusyawaratan Ulama (MPU) di Aceh, menjelaskan sejarah eksistensi peran Ulama di Aceh dan juga menganalisis aspek hukum dan implikasi hukum penetapan fatwa MPU Aceh tentang aliran sesat.Pendekatan yang digunakan dalam kajian ini adalah pendekatan peraturan perundang-undangan (statute approach), Pendekatan Kasus (Cases Approach), dan dikombinasikan dengan pendekatan Sejarah (Hsitorical Approach). Hasil kajian menunjukkan bahwa fatwa yang ditetapkan oleh MPU Aceh tentang aliran sesat kepada beberapa pimpinan dayah/pasantren di Provinsi Aceh bertentangan dengan hukum, tepatnya Pasal 5 huruf b Qanun Aceh No. 2 Tahun 2009 tentang Majelis Permusyawaratan Ulama.
\end{abstract}

Kata Kunci: fatwa, Majelis Permusyawaratan Ulama Aceh, aliran sesat.

\section{Pendahuluan}

Majelis Permusyawaratan Ulama Aceh dalam dua tahun terkahir yaitu tahun 2012 dan 2013 telah mengeluarkan fatwa sesat dan menyesatkan kepada beberapa dayah/pasantren yang terdapat di beberapa kabupaten/kota di Aceh. Salah satu diantaranya fatwa sesat dan menyesatkan yang dikeluarkan oleh MPU terhadap ajaran yang dikembangkan oleh aliran Laduni di Laduni di Kecamatan Kaway XVI, Aceh Barat di tahun 2012. Terkait dua aliran ini, utusan ulama dari kabupaten dan kota se-Aceh sudah bermusyawarah sejak 15-17 Oktober 2012.

Fatwa sesat dan menyesatkan juga ditetapkan oleh MPU Aceh kepada aliran yang dikembangkan oleh pengelola beserta para santri Dayah Baitul Mu'arrif di Kecamatan Meurah Meulia, Balai Pengajian Mubtadi'ul Ulum, Syamta- lira Bayu, Aceh Utara. MPU Aceh juga mengeluarkan fatwa sesat dan menyesatkan terhadap ajaran yang dikembangkan oleh Pimpinan Yayasan Al-Mujahadah di Desa Ujong Kareung, Kecamatan Sawang, Kabupaten Aceh Selatan, Tgk Ahmad Barmawi melalui Fatwa Majelis Permusyawaratan Ulama Aceh Nomor 1 Tahun 2013. ${ }^{1}$ Fatwa sesat dan menyesatkan terhadap Pimpinan Yayasan Al-Mujahadah tersebut dibacakan oleh Kepala Sekretariat MPU Aceh, Saifuddin Puteh, di Hotel Kuala Radja Banda Aceh yang disaksikan para ketua Majelis Permusyawartan Ulama (MPU) dari kabupaten/kota se-Aceh. ${ }^{2}$

\footnotetext{
"MPU Fatwakan Ajaran Ahmad Barmawi Sesat", tersedia di Website http://aceh.tribunnews.com/2013/ 03/01/mpu-fatwakan-ajaran-ahmad-barmawi-sesat, diakses tanggal 2 Januari 2014.

2 Ibid.
} 
MPU Aceh selain mengluarkan fatwa, juga menyampaikan tausiah yang intinya meminta pemerintah mencabut izin operasional Yayasan Al-Mujahadah Desa Ujong Kareung, Kecamatan Sawang, Aceh Selatan, dan menutup pengajian dan penyebaran pemahaman, pemikiran, dan pengamalan yang dikembangkan Tgk Ahmad Barmawi dan seumpamanya serta mengawasi perkembangannya. ${ }^{3}$ MPU Aceh meminta pemerintah menertibkan setiap aktivitas LSM dan pengajian agama yang berkedok pengobatan alternatif, aktivitas bela diri, dan lainnya, menertibkan aktivitas pengajian dan membentuk tim verifikasi bahan/kitab/buku kajian keagamaan bidang fikih, tauhid, akhlak, dan tasawuf yang muktabarah. Majelis Permusyawaratan Ulama (MPU) Aceh juga meminta masyarakat untuk tidak mengikuti pengajian, ceramah, dan diskusi yang menyiampang dari ajaran Islam, seperti ajaran Tgk Ahmad Barmawi dan sejenisnya. Orang tua juga diimbau untuk tidak mengantarkan anaknya ke lembaga pendidikan yang mengajarkan ajaran-ajaran yang menyimpang dari Islam seperti ajaran Tgk Ahmad Barmawi dan sejenisnya. Selain itu MPU juga minta pada Tgk Ahmad Barmawi dan pengikutnya bertobat dan kembali kepada ajaran yangbenar.

Setelah dikeluarkannya fatwa sesat dan menyesatkan kepada ajaran yang dikembangkan oleh Tgk Ahmad Barmawi, Pimpinan Yayasan Al - Mujahadah tersebut, selasa malam tanggal 5 Maret 2013, ratusan massa mendatangi pasantren tersebut. ${ }^{4}$ Meskipun TNI akhirnya berhasil membubarkan massa pada jam 23.00 WIB, namun massa mengancam akan kembali besok Rabu, 06 Maret 2013 dengan jumlah lebih besar. ${ }^{5}$ Keesokan harinya ratusan masyarakat mendatangi yayasan Al- Mujahadah bersamaan dengan rombongan Muspida dan Muspika setempat yang hendak menyegel dayah tersebut. Setiba di lokasi, perwakilan dari Muspida kemudian membacakan fatwa MPU dan setelah itu massa lang-

\footnotetext{
Ibid.

"Korban Fatwa Sesat MPU Dikepung Masa, Negara Harus Jamin Keamanan", tersedia di Website http://potretonline.com/index.php/news-flash/1262-korban-fatwasesat-mpu-dikepung-massa-negara-harus-jamin-keamanan, diakses tanggal 2 Januari 2014.

5 lbid.
}

sung merusak pagar dan juga papan nama dayah. Ironisnya, Satuan Polisi Pamong Praja (Satpol PP) juga ikut merusak papan nama dayah tersebut. Bahkan di papan nama Dayah Al-Muhajadah itu pun ditempel tulisan "Ajaran Sesat dan Menyesatkan".

Fatwa yang telah dikeluarkan oleh Majelis Permusyawaratan Ulama (MPU) Aceh mengenai aliran sesat dan menyesatkan tersebut kecenderungannya selalu diikuti dengan tindakan kekerasan oleh masyarakat setempat baik berupa pengerusakan pagar dan papan nama dayah, pengusiran, pemukulan, tindakan kriminal berupa pembakaran hidup-hidup (seperti yang dialami Tgk Aiyub di Plimbang, Kab. Bireuen), serta berbagai bentuk kekerasan lainnya. Keresahan pun selalu menghantui para pimpinan dayah maupun para santri yang sedang menuntut ilmu agama di Dayah/Pasantran yang di fatwakan sesat dan menyesatkan tersebut. Aceh yang dikenal dengan sebutan "Negeri Serambi Makkah" yang masyarakatnya taat dan memegang teguh prinsip Islam dalam kehidupan kesehariannya, justru menampilkan sisi kekerasan (yang justru ditentang oleh Islam) terhadap para pimpinan pasantren maupun santri sebagai objek yang difatwakan sesat dan menyesatkan oleh Majelis Permusyawaratan (MPU) Aceh.

Berbagai fatwa tentang aliran sesat dan menyesatkan yang dikeluarkan oleh Majelis Permusyawartan Ulama (MPU) Aceh tersebut telah menimbulkan sikap intoleransi dalam beragama serta menimbulkan instabilitas keharmonian di tengah masyarakat Aceh yang beragam. Situasi ini menimbulkan keperihatinan dari pemerintah daerah maupun pemerintah pusat. Berbagai kalangan aktifis di Aceh pun turut memberikan reaksi dan kecamatan keras baik kepada masyarakat setempat sebagai aktor maupun kepada MPU Aceh yang telah mengeluarkan fatwa sesat dan menyesatkan tersebut. Diantara beberapa aktifis tersebut adalah Jaringan Masyarakat Sipil Peduli Syariat (JMSPS) yang meminta MPU tidak mengeluarkan fatwa sesat atau menjurus sesat terhadap komunitas tertentu karena akan menimbulkan kekerasan dalam masyarakat. Masyarakat butuh bimbingan ulama dalam meng- 
hadapi perbedaan-perbedaan pandangan agama, bukan fatwa saling menyesatkan sebagaimana pesan yang disampaikan oleh Juru Bicara Jaringan Masyarakat Sipil Peduli Syariat (JMSPS), Affan Ramli melalui siaran persnya. Selain itu juga, Aceh Judicial Monitoring Insititute (AJMI) turut mengecam sikap yang dilakukan oleh MPU Aceh. Berdasarkan latar belakang diatas, penulis tertarik untuk mengkaji mengenai aspek dan implikasi yuridis keberadaan fatwa Majelis Permusyawaratan Ulama (MPU) Aceh tentang paham atau aliran sesat.

\section{Pembahasan}

\section{Landasan Konstitusional MPU Aceh}

Keberadaan MPU di Aceh merupakan wujud daripada manifestasi komitmen negara yang mengakui serta menghormati satuan-satuan pemerintahan daerah tertentu yang bersifat khusus maupun bersifat istimewa. Hal tersebut secara tegas dijabarkan dalam UUD 1945 sebagai konstitusi negara sebagaimana yang tercantum dalam Pasal 18B ayat (1) UUD 1945 menyebutkan bahwa: "Negara mengakui dan menghormati satuan-satuan pemerintahan daerah yang bersifat khusus atau bersifat istimewa yang diatur dengan undang-undang". Rumusan Pasal 18B ayat (1) tersebut secara nyata menunjukkan bahwa para elit negara ini menyadari akan keragaman budaya dan sejarah setiap daerah yang ada di Indonesia. ${ }^{6}$

Keragaman budaya maupun sejarah tersebut telah membuka ruang adanya status daerah yang bersifat khusus maupun bersifat istimewa kepada satuan pemerintahan tertentu di Indonesia. Perkataan "khusus" memiliki cakupan luas, antara lain dimungkinkan untuk membentuk pemerintahan daerah dengan otonomi khusus seperti Aceh dan Irian Jaya. ${ }^{7}$ Sebagai bentuk manifestasi daripada amanat Pasal 18B ayat (1) konstitusi tersebut menyangkut status satuan

\footnotetext{
Kurniawan, "Eksistensi Masyarakat Hukum Adat dan Lembaga-Lembaga Adat di Aceh dalam Penyelenggaraan Keistimewaan dan Otonomi Khusus di Aceh", Jurnal Hukum YUSTISIA, Vol. 84 No. 22 September - Desember 2012, Surakarta: FH UNS, hlm. 49.

7 Husni Jalil, dkk, "Implementasi Otonomi Khusus di Provinsi Aceh berdasarkan Undang-Undang Nomor 11 Tahun 2006",Jurnal Ilmu Hukum KANUN, No. 51 Tahun XII Agustus 2010,Aceh: FH UNSIYAH,hlm. 206-207.
}

pemerintahan yang bersifat khusus atau bersifat istimewa tersebut, maka pemerintah menge-sahkan beberapa daerah tertentu yang meme-nuhi syarat secara materil maupun secara histo-ris akan status tersebut.

Daerah-daerah di Indonesia yang mendapatkan status otonomi khusus diberikan oleh Pemerintah hanya kepada dua provinsi di Indonesia yaitu Provinsi Aceh dan Provinsi Irian Jaya. Status Otonomi Khusus bagi Provinsi Aceh diberikan oleh Pemerintah dengan disahkannya Undang-Undang Nomor 18 Tahun 2001 tentang Otonomi Khusus bagi Provinsi Daerah Istimewa Aceh sebagai Provinsi Nanggroe Aceh Darussalam sebagaimana telah dicabut dengan UndangUndang Nomor 11 Tahun 2006 tentang Pemerintahan Aceh. Adapun Otonomi Khusus bagi Provinsi Papua diberikan oleh Pemerintah dengan disahkannya Undang-Undang Nomor 21 Tahun 2001 tentang Otonomi Khusus Papua.

Provinsi Aceh selain mendapatkan status Otonomi khusus secara bersamaan menyandang status istimewa. Status istimewa bagi Provinsi Aceh disematkan oleh Pemerintah seiring dengan disahkannya Undang-Undang Nomor $44 \mathrm{Ta}$ hun 1999 tentang Penyelenggaraan Keistimewaan Provinsi Daerah Istimewa Aceh. Adapun halhal pokok yang ditetapkan dalam Undang-Undang Nomor 44 Tahun 1999 tersebut, untuk menyelenggarakan keistimewaan Aceh dan tidak diberikan kepada daerah-daerah lainnya di Indonesia. ${ }^{8} \mathrm{Hal}$ ini bermakna bahwa provinsi Aceh merupakan satu-satunya daerah di Indonesia yang satuan pemerintahan daerahnya mendapatkan dua buah status secara bersamaan sebagaimana yang diamanatkan dalam Pasal 18B ayat (1) Undang-Undang Dasar Negara Republik Indoensia Tahun 1945, yaitu status Istimewa dan status Otonomi Khusus.

\section{Landasan Hukum MPU Aceh}

Berdasarkan amanat konstitusi mengenai status satuan pemerintahan yang bersifat khusus atau bersifat istimewa sebagaimana yang

\footnotetext{
Mohammad Daud Yoesoef, "Oanun Sebagai Aturan Pelaksana Peraturan Perundang-Undangan Atasan", Jurnal Ilmu Hukum KANUN, No. 47 Tahun IX Agustus 2009, Aceh: FH UNSIYAH, hlm. 178.
} 
diatur dalam Pasal 18B ayat (1) Undang-Undang Dasar Negara Republik Indonesia Tahun 1945 tersebut, maka untuk Aceh dikeluarkanlah Undang-Undang Nomor 44 Tahun 1999 tentang Penyelenggaraan Keistimewaan Provinsi Daerah Istimewa Aceh. Undang-Undang Nomor $44 \mathrm{Ta}$ hun 1999 tersebut hakikatnya telah mengamanatkan kepada Aceh untuk menyelenggarakan keistimewaan yang salah satunya penyelenggaraan kehidupan beragama (syari'at Islam), sebagaimana yang ditegaskan dalam Pasal 3 ayat (2) menyebutkan bahwa:

Penyelenggaraan Keistimewaan meliputi:

a. Penyelenggaraan kehidupan beragama;

b. Penyelenggaraan kehidupan adat;

c. Penyelenggaraan pendidikan; dan

d. Peran ulama dalam penetapan kebijakan Daerah.

Keistimewaan yang dimaksud dalam Undang-Undang Nomor 44 Tahun 1999 tersebut adalah kewenangan khusus untuk menyelenggarakan kehidupan beragama, adat, pendidikan, dan peran ulama dalam penetapan kebijakan Daerah sebagaimana yang dijelaskan dalam $\mathrm{Pa}$ sal 1 angka 8. Istilah "Keistimewaan" sebagaimana dimaksud dalam Undang-Undang Nomor 44 Tahun 1999 tersebut merupakan pengakuan dari bangsa Indonesia yang diberikan kepada daerah karena perjuangan dan nilai-nilai hakiki masyarakat yang tetap dipelihara secara turun temurun sebagai landasan spiritual, moral dan kemanusiaan sebagaimana yang diamanatkan dalam Pasal 3 Undang-Undang Nomor 44 Tahun 1999.

Diformalisasikannya syari'at Islam dalam penyelenggaraan kehidupan beragama di Aceh sebagai bentuk keistimewaan yang diberikan Pemerintah kepada Aceh tersebut bukan secara tiba-tiba(plotseling) dan tanpa sebab maupun pertimbangan (zonder rekening te houden), melainkan secara fundamental karena ada faktor pertimbangan sejarah (historical cinsideration)dimasa masa lalu yang panjang. ${ }^{9}$ Dasar pertimbangan sejarah tersebut yaitu karena tiga hal sebagaimana yang tercantum dalam kon-

9 Kurniawan, “Dinamika Formalisasi Syari'at Islam di Indonesia", Jurnal Ilmu Hukum KANUN, No. 58 Tahun XIV Desember 2012,Aceh: FH UNSIYAH, hlm. 453. sideran menimbang huruf $a$, huruf $b$ dan huruf $c$ dalam Undang-Undang Nomor 44 Tahun 1999 tentang Penyelenggaraan Keistimewaan Provinsi Daerah Istimewa Aceh. Pertama, bahwa sejarah panjang perjuangan rakyat Aceh membuktikan adanyaketahanan dan daya juang yang tinggi, yang bersumber dari kehidupan yang religius, adat yang kukuh, dan budaya Islam yang kuat dalam menghadapi kaum penjajah; kedua, bahwa kehidupan religius rakyat Aceh yang telah membentuk sikap pantang menyerah dan semangat nasionalisme dalam menentang penjajah dan mempertahankan kemerdekaan merupakan kontribusi yang besar dalam menegakkan Negara Kesatuan Republik Indonesia meskipun rakyat Aceh kurang mendapat peluang untuk menata diri; ketiga, bahwa kehidupan masyarakat Aceh yang religius, menjunjung tinggi adat, dan telah menempatkan ulama pada peran yang terhormat dalam kehidupan bermasyarakat, berbangsa, dan bernegara perlu dilestarikan dan dikembangkan bersamaan dengan pengembangan pendidikan. Ketiga dasar petimbangan sejarah tersebut yang menjadi pertimbangan pemerintah sehingga menetapkan status keistimewaan bagi Aceh sebagai manifestasi tuntutan kehendak para pemimpin Aceh di masa lalu yang belum terpenuhi secara utuh.

Undang-undang No. 44 Tahun 1999 tersebut dijadikan sebagai landasan hukum atau alas hak bagi Pemerintah Aceh dalam memben-tuk beberapa lembaga keistimewaan dalam rangka manifestasi dari status istimewa yang telah diberikan dengan telah disahkannya Undang-Undang Nomor 44 Tahun 1999. Beberapa lembaga keistimewaan tersebut adalah sebagai berikut: Dinas Syari'at Islam, Wilayatu Hisbah (WH) atau Polisi Syari'ah, Mahkamah Syari'ah, Majelis Permusyawaratan Ulama (MPU) Aceh, Majelis Pendidikan Daerah (MPD), Majelis Adat Aceh (MAA) dan Baitul Maal.

Kelembagaan MPU Acehsebagaimana yang disebutkan diatas dibentuk melalui Pera-turan Daerah Istimewa Aceh Nomor 3 Tahun 2000 tentang Pembentukan Organisasi dan Tata Kerja Majelis Permusyawaratan Ulama Provinsi Daerah Istimewa Aceh. Keberadaan Lembaga MPU 
Aceh merupakan sebagai instrumen untuk melaksanakan status keistimewaan Aceh dalam bidang peran ulama dalam penetapan kebijakan daerah sebagaimana yang diamanatkan dalam Pasal 3 ayat (2) huruf d Undang-Undang Nomor 44 Tahun 1999 tentang Penyelenggaraan Keistimewaan Provinsi Daerah Istimewa Aceh. ${ }^{10}$

Peraturan Daerah Istimewa Aceh Nomor 3 Tahun 2000 tentang Pembentukan Organisasi dan Tata Kerja Mejelis Permusyawaratan Ulama Provinsi Daerah Istimewa Aceh tersebut selanjutnya diubah dengan Peraturan Daerah Istimewa Aceh Nomor 43 Tahun 2001 tentang Perubahan Atas Peraturan Daerah Provinsi Daerah Istimewa Aceh Nomor 3 Tahun 2000 tentang Pembentukan Organisasi dan Tata Kerja Mejelis Permusyawaratan Ulama Provinsi Daerah Istimewa Aceh. Pada Tahun 2009, kedua Peraturan Daerah tersebut dicabut dan dinyatakan tidak berlaku lagi seiringdengan telah disahkannya Qanun Aceh Nomor 2 Tahun 2009 tentang Majelis Permusyawaratan Ulama.

Pemerintah Aceh telah mengeluarkan beberapa peraturan daerah atau Qanun Aceh sebagai peraturan lanjutan atau peraturan organik yang ditujukan untuk melaksanakan secara teknis alam penyelenggaraan keistimewaan tersebut yang salah satunya menyangkut dengan penyelenggaraan kehidupan beragama dan juga menyangkut adanya peran ulama dalam penetapan kebijakan daerah. ${ }^{11}$ Beberapa peraturan lanjutan atau peraturan organik tersebut sebagai pijakan dasar dalam penerapan syari'at Islam secara menyeluruh adalah sebagai berikut. Pertama, Peraturan Daerah Provinsi Daerah Istimewa Aceh Nomor 5 Tahun 2000 tentang Pelaksanaan Syari'at Islam (Lembaran Daerah Provinsi Daerah Istimewa Aceh Tahun 2000 Nomor 30); kedua, Peraturan Daerah Provinsi Nanggroe Aceh Darussalam Nomor 10 Tahun 2002 tentang Peradilan Syari'at Islam (Lembaran Daerah Provinsi Nanggroe Aceh Darussalam Tahun 2003 No-

10 Zainal Abidin, “Pemberlakuan Syari'at Islam sebagai Hukum Positif di Provinsi Aceh", Jurnal Ilmiah Ilmu-ilmu Sosial dan Kemasyarakatan MONDIAL, Vol. 12 No. 21 Januari - Juni 2010, Aceh: UPT Perpustakaan UNSIYAH, hlm. 134.

11 Danial dkk, "Pelaksanaan Syari'at Islam dan Kekerasan di Aceh", Jurnal Kajian Aceh Seumike', Vol. 3 No. 1 November 2007,Aceh: Aceh Institute Press, hlm. 62. mor 2 Seri E Nomor 2, Tambahan Lembaran Daerah Provinsi Nanggroe Aceh Darussalam Nomor 4); ketiga, Qanun Aceh Nomor 11 Tahun 2002 tentang Pelaksanaan Syari'at Islam Bidang Aqidah, Ibadah, dan Syi'ar Islam; keempat, Qanun Aceh Nomor 12 Tahun 2003 tentang Larangan Khamar; kelima, Qanun Aceh Nomor 13 Tahun 2003 tentang Maisir; keenam, Qanun Aceh Nomor 14 tahun 2003 tentang Khalwat; ketujuh, Qanun Aceh Nomor 7 Tahun 2004 tentang Pengelolaan Zakat; kedelapan, Qanun Aceh Nomor 11 Tahun 2004 tentang Fungsional Kepolisian Daerah Nanggroe Aceh Darussalam; kesembilan, Qanun Aceh Nomor 2 Tahun 2009 tentang Majelis Permusyawaratan Ulama.

Undang-undang No. 44 Tahun 1999 tentang Penyelenggaraan Keistimewaan Provinsi Daerah Istimewa Aceh telah menempatkan ProvinsiAceh sebagai satu-satunya daerah di wilayah Negara Kesatuan Republik Indonesia yang secara hukum mendapat pengakuan formal (Legal Formal Recognation) akan berlakunya pelaksanaan syari'at Islam dalam rangka manifestasi daripada jaminan pengakuan negara terhadap satuan-satuan pemerintahan daerah yang bersifat khusus dan istimewa sebagaimana yang diamanatkan dalam Pasal 18B ayat (1) UUD $1945 .^{12}$ Guna memperkuat keberadaan penyelenggaraan keistimewaan Aceh dibawah rezim Undang-Undang Nomor 44 Tahun 1999 tersebut sekaligus guna memberi kewenangan yang luas dalam menjalankan pemerintahan bagi Provinsi Daerah Istimewa Aceh, sesuai dengan amanat TAP MPR No. IV/MPR/1999 maka disahkan Undang-Undang Nomor 18 Tahun 2001 tentang Otonomi Khusus bagi Provinsi Daerah Istimewa Aceh sebagai Provinsi Nanggroe Aceh Darussalam. ${ }^{13}$ Undang-Undang Nomor 18 Tahun 2001 pada prinsipnya mengatur kewenangan yang bersifat khusus kepada Pemerintah Provinsi Nanggroe Aceh Darussalam yang berbeda dari kewenangan pemerintahan daerah sebagaimana

\footnotetext{
12 Kurniawan, "Demokrasi dan Konstitusionalisme Hukum Islam di Indonesia", Jurnal Ilmu Hukum KANUN, No. 55 Tahun XIII Desember 2011,Aceh: FH UNSIYAH, hlm. 380.

13 Hasan Basri, "Kedudukan Syari'at Islam di Aceh Dalam Sistem Hukum Indonesia", Jurnal IImu Hukum KANUN, No. 55 Tahun XIII Desember 2011, hlm. 319.
} 
yang diatur dalam Undang-Undang Nomor 32 Tahun 2004 tentang Pemerintahan Daerah. ${ }^{14}$

Keberadaan status keistimewaan bagi Aceh semakin menghujam kedalam sistem hukum nasional dengan lahirnya Undang-Undang Nomor 11 Tahun 2006 tentang Pemerintahan Aceh menggantikan Undang-Undang Nomor 18 Tahun 2001 tersebut.Undang-Undang Nomor 11 Tahun 2006 merupakan hasil kesadaran yang kuat dari Pemerintah dan Gerakan Aceh Merdeka (GAM) untuk menyelesaikan konflik secara damai, menyeluruh, berkelanjutan serta bermartabat yang permanen dalam kerangka NKRI. ${ }^{15}$ Namun, materi muatan yang terkandung dalam Undang-Undang Nomor 11 Tahun 2006 tersebut mempunyai beberapa perbedaan signifikan dengan materi muatan yang terkandung dalam Memorendum of Understanding (MoU) yang ditandatangani oleh para pihak (Pemerintah dan Wakil GAM). ${ }^{16}$

\section{Keistimewaan Aceh dalam Lintasan Sejarah}

Perjalanan sejarah praktek ketatanegaraan di Indonesia telah menempatkan Aceh sebagai pemerintahan yang bersifat istimewa dan khusus. Pemberian kedua status tersebut terkait dengan katakter khas sejarah perjuangan masyarakat Aceh yang memiliki ketahanan dan daya juang tinggi bersumber dari pandangan hidup yang berlandaskan syari'at Islam yang melahirkan budaya Islam yang kuat.

Kehidupan rakyat Aceh yang religius telah membentuk sikap pantang menyerah dan memiliki semangat nasionalisme yang kuat dalam mempertahankan kemerdekaan, sehingga menempatkan Aceh menjadi daerah modal bagi perjuangan dalam merebut dan mempertahan-

14 Eddy Purnama, "Refleksi Otonomi Khusus Berdasarkan Undang-Undang Nomor 11 Tahun 2006“, Jurnal Ilmiah Ilmu-ilmu Sosial dan Kemasyarakatan MONDIAL, Vol. 12 No. 21 Januari - Juni 2010, Aceh: UPT Perpustaan UNSIYAH, hlm. 3.

15 Sulaiman, "Keadilan Bagi Korban Pelanggaran Berat HAM Masa Lalu di Aceh", Jurnal Hukum dan Keadilan MEDIASI, Vol. 1 No. 3 September 2011, Aceh: UNMUHA, $\mathrm{hlm} .33$.

16 Galuh Wandita, Patrick Burgess, “Minum Kopi Pahit Asli Aceh: Membuka Jendela-jendela Pertanggungjawaban Atas Kekerasan Masa Lalu", Jurnal Kajian Aceh Seumike', Vol. 4 No. 21 Februari 2009, Aceh: Aceh institute Press, hlm. 29. kan kemerdekaan Negara Kesatuan Republik Indonesia pada masa revolusi fisik. Perjuangan dan pengorbanan rakyat Aceh dalam mempertahankan kemerdekaan RI melalui peran ulama yang sangat dominan dan masif, telah menempatkan Aceh sebagai salah satu daerah yang memiliki kedudukan tersendiri.

Penghayatan terhadap ajaran Islam yang telahmelekat tersebut melahirkan budaya Aceh yang tercermin dalam kehidupan adat sehingga tergambarkan dalam hadis majah (kata-kata bijak) yaitu: "Adat bak poteumeureuhom, hukom bak Syiah Kuala, Qanun bak putroe Phang, reusam bak laksamana". Kalimat tersebut bermakna bahwa: "hukum adat ditangan pemerintah, dan hukum syari'at ditangan ulama". ${ }^{17}$ Untaian kata-kata sebagai-mana yang terdapat dalam hadis maja tersebut merupakan pencerminan dan perwujudan syari'at Islam dalam praktik kehidupan sehari-hari bagi masyarakat Aceh. ${ }^{18}$ Selanjutya oleh karena letaknya di wilayah paling barat, maka Aceh dikenal sebagai Daerah Serambi Makkah dimana kaum muslimin dari berbagai wilayah di Nusantara berangkat ke Tanah Suci Makkah untuk menunaikan rukun Islam yang ke-lima.

Semenjak Islam lahir pada abad VI, Aceh merupakan tempat pertama yang menerima Islam di Asia Tenggara. Menurut catatan pengembara barat, Aceh menjadi sebuah kerajaan Islam pada abad XIII Masehi, yang selanjutnya berkembang menjadi sebuah kerajaan yang maju pada abad XIV Masehi yang selanjutnya berkembang ke seluruh Asia Tenggara. ${ }^{19}$ Pada sekitar abad XV Masehi ketika bangsa barat memulai petualangannya di wilayah timur, hampir sebagian besar wilayah nusantara berhasil dikuasai, tetapi Aceh tetap bebas sebagai sebuah kerajaan yang berdaulat.

17 Taqwaddin, "Kewenangan Mukim dalam Pengelolaan Sumber Daya Alam",Jurnal Ilmu Hukum KANUN, No. 48 Tahun 9 Desember 2009, Aceh: FH UNSIYAH, hlm. 328.

18 Malik Musa, "Kewenangan, Peran, dan Tugas Lembaga Tuha Peut di Aceh", Jurnal Hukum dan Keadilan MEDIASI, Vol. 1 No. 3 Mei 2011. Aceh: FH UNMUHA, hlm. 3.

19 Teuku Muttaqin Mansur, Faridah jalil, "Aspek Hukum Peradilan Adat di Indonesia Periode 1602-2009", Jurnal IImu Hukum KANUN, No. 59 Tahun XIV April 2013, Aceh: FH UNSIYAH, hlm. 65. 
Hubungan Kerajaan Aceh Darussalam dengan Kerajaan Belanda tercatat dalam percaturan internasional cukup baik, namun pada abad XVI hubungan diantara kedua kerajaan tersebut mengalami krisis. ${ }^{20}$ Meski demikian dalam Traktat London 17 Maret 1824, Pemerintah Belanda berjanji kepada Pemerintah Inggris untuk tetap menghormati kedaulatan Kerajaan Aceh. ${ }^{21} \mathrm{Em}$ pat puluh tujuh tahun kemudian, dengan berbagai kelicikan, Belanda meyakinkan Inggris untuk tidak menghalangi menguasai Aceh melalui Traktat Sumatra 1 November 1871.22 Dua tahun kemudian (1873) Kerajaan Belanda menyerang Aceh dan berkobarlah peperangan yang berlangsung puluhan tahun dengan menalan korban yang banyak diantara kedua belah pihak. ${ }^{23} \mathrm{Se}$ jak saat itu hingga perang dunia kedua, Kerajaan Belanda telah kehilangan enam jenderal dan ribuan perwiran dan para prajurit.

Komitmen kebangsaan rakyat Aceh terhadap Republik Indoneisa tidak pernah surut dalam perjalanan sejarah kemerdekaan Indonesia. Setelah Proklamasi kemerdekaan, para pemuda Aceh umumnya ikut dalam perjuangan untuk membela negara dengan turut bergabung dalam Tentara keamanan Rakyat (TKR) yang selanjutnya berubah menjadi Tentara Rakyat Indonesia(TRI) selanjutnya berubah menjadi tentara Nasional Indonesia (TNI). Dua bulan setelah Proklamasi kemerdekaan Indonesia tanggal 17 Agustus 1945, tepatnya tanggal 7 Oktober 1945, empat orang ulama besar Aceh mengeluarkan fatwa yang menegaskan bahwa:

"bagi kaum Muslimin yang berperang untuk mempertahankan cita-cita proklamasi yang apabila ia meninggal dalam perang tersebut akan mendapatkan pahala syahid". ${ }^{24}$

Keempat ulama besar tersebut juga menganjurkan rakyat berdiri teguh di belakang pemimpin bangsa Indonesia yang sedang berjuang. Ada pun keempat ulama Aceh yang melegenda ter-

20 Kaoy Syah, 2004, Keistimewaan Aceh Dalam Lintasan Sejarah, Jakarta: Pengurus Besar Al-Jami’iyatul Washliyah, hlm. 2.

21 Ibid.

22 Ibid.

23 Ibid.

24 Ibid., hlm. 63 - 64 sebut yaitu: Tgk. H. Jakfar Lamjabat, Tgk. H. Muhammad Hasan Krueng Kalee, Tgk. H. Ahmad Hasballah Indera Puri, dan Tgk. H. Muhammad Daud Beureueh. ${ }^{25}$

Seluruh wilayah Republik Indonesia, pada akhir tahun 1948 telah berhasil diduduki oleh Kerajaan Belanda ketika dilancarkannya agresi Militer Belanda Kedua, kecuali daerah Aceh. Oleh karena itu, maka Soekarno menem-patkan Aceh sebagai "Daerah Modal" untuk mempertahankan kemerdekaan Negara Indonesia yang telah diproklamasikan pada tahun 1945. Presiden Soekarno dalam beberapa waktu berkunjung ke Aceh dalam upaya merebut simpati rakyat Aceh untuk terus mengobarkan semangat melawan kolonialisme Belanda.

Presiden Soekarno dalam sebuah pidatonya di Lapangan Blang Padang, Kuta Raja (saat ini bernama kota Banda Aceh) tanggal 17 Juni 1948, di depan lebih dari 100 ribu rakyat Aceh yang datang telah membakar semangat perjuangan rakyat Aceh dalam kobaran garangnya orasi heroik patriotik dengan kutipan kata sebagai berikut: ${ }^{26}$

"Dari ribuan kilometer aku datang ke sini spesial untuk bertemu dengan rakyat Aceh yang terkenal sebagai satu rakyat yang selalu berjuang untuk kemerdekaan, yang selalu menjadi kampiun dan pelopor perjuangan kemerdekaan rakyat Indonesia. Segenap rakyat Indonesia di Tanah Jawa, Sumatra, Sunda Kecil, Kalimantan, Sulawesi, dan pulau-pulau lainnya mengarahkan matanya kepada saudara-saudara. Pokoknya, saudara punya perjuangan sekarang ini ialah perjuangan menyelamatkan Republik Indonesia, republik yang sekarang menjadi kecil sesudah terjadi-nya perang kolonial pada Juli 1947 tahun lalu, tetapi dengan Aceh menjadi Daerah Modal seluruh wilayah Republik Indonesia akan kita rebut kembali.Terus saudarasaudara tidak salah sangka aku, semangat Aceh memang bergelora, menjadi modal bagi perjuangan bangsa Indonesia".

Pada tanggal 16 Juli 1948, Presiden Soekarno mengunjungi Aceh dan mengumpulkan para tokoh dan pedagang Aceh untuk mengga-

25 Ibid., hlm. 64.

26 Ibid., hlm. 64 - 65 
lang kekuatan dan bantuan untuk mendukung perjuangan dalam mempertahankan kemerdekaan Indonesia. Presiden Soekarno memberikan pidato politiknya di Pendopo Residen Aceh berkata: ${ }^{27}$

"hanya jikalau negara Indonesia telah berdiri dengna isinya, jikalau sang merah putih telah berkibar di seluruh kepulauan Indonesia, barulah kita boleh berkata bahwa revolusi nasional kita telah selesai. Saya tahu rakyat Aceh adalah pahlawan. Aceh selalu menjadi contoh teladan bagi perang kemerdekaan, contoh perang kemerdekaan seluruh rakyat Indonesia. Seluruh rakyat Indonesia melihat ke Aceh, mencari kekuatan batin dari Aceh, dan Aceh menjadi obor perjuangan rakyat Indonesia".

Rapat raksasa tangal 18 Juli 1948 di Bireuen, Presiden soekarno sekali lagi berpidato di depan lebih seratus ribu rakyat Aceh berkata: ${ }^{28}$

"Aku ingin bertemu muka dengan rakyat Aceh yang selalu menjadi kenanganku, rakyat yang tidak mau dijajah Belanda.... Rakyat yang telah mengalahkan tentara Belanda.... yang telah mengadakan perjuangan mati-matian, bertempur, menolak dan menahan imperialisme Belanda masuk ke Daerah Aceh, sehingga karenanya Aceh menjadi Daerah Modal Republik Indonesia......".

Paska kunjungan Presiden Soekarno ke Aceh tersebut berdasarkan himbaun Soekarno dengan ditopang oleh pengaruh kharismatik Tgk. Abu Daud Ber'euh (sebagai ulama sekaligus pimpinan militer), akhirnya semua anggota masyarakat terutama para pedagang mengumpulkan dana dan emas untuk membeli sebuah kapal terbang sebagai sarana bagi pemimpin Indonesia untuk melakukan lobi-lobi secara masif di tingkat internasional dalam upaya mendapatkan simpatik dari berbagai peimimpin dunia.

Tokoh Aceh yang menjadi Gubernur Militer ketika itu Tgk. M. Daud Beureu'eh sebelum Soekarno kembali Ke Ibu Kota Jakarta,meminta jaminan dari Presiden RI pertama Ir. Soekarno

27 Ibid., hlm.64.

28 Ibid., hlm.65. untuk memberikan kebebasan kepada rakyat Aceh melaksanakan unsur-unsur syari'at Islam dalam seluruh aspek hidup dan kehidupan. ${ }^{29} \mathrm{Be}$ rikut dialog antara Presiden Soekarno dengan Tgk. Abu Daud Beureu'eh yang dikutip dari buku Referendum Aceh dalam Pantauan Hukum Karya Sofyan Ibrahim Tiba S.H. sebagai berikut: ${ }^{30}$

Presiden Soekarno (PS): "Saya meminta bantuan Kakak (Daud Beureu'eh), agar rakyat Aceh turut mengambil bagian dalam perjuangan bersenjata yang sekarang sedang berkobar antara Indonesia dengan Belanda untuk mempertahankan kemerdekaan yang telah kita proklamirkan pada tanggal 17 agustus 1945."

Daud Beureu'eh (DB): "Saudara Presiden! Kami rakyat Aceh dengan segala senang hati dapat memenuhi permintaan Presiden, asal saja perang yang akan kami kobarkan itu, berupa perang sabil atau perang fii sabilillah, perang untuk menegakkan agama Allah, sehingga kalau ada di antara kami yang terbunuh dalam peperangan tersebut berarti mati syahid".

PS: "Kakak! Memang yang saya maksud itu adalah perang seperti yang telah dikobarkan oleh para pahlawan Aceh yang terkenal seperti Tengku Chikditiro dan lain-lain, yaitu pe-rang yang tidak kenal mundur, perang yang bersemboyan 'merdeka atau syahid".

DB: "kalau begitu kedua pendapat kita telah bertemu saudara Presiden. Dengan demikian bolehlah saya mohon kepada Saudara Presiden, bahwa apabila perang telah usai nanti, kepada rakyat Aceh diberi kebebasan untuk menjalankan syari'at Islam dalam daerahnya".

PS: "Mengenai itu Kakak tidak usah khawatir, sebab $90 \%$ rakyat Indonesia beragama Islam".

DB: Maafkan saya Saudara Presiden, kalau saya terpaksa mengatakan bahwa hal itu tidak menjadi jaminan bagi kami. Kamikami menginginkan satu kata ketentuan dari Saudara Presiden".

PS: "Kalau demikian baiklah saya setuju permintaan Kakakku".

DB: "Alhamdulillah. Atas nama rakyat Aceh saya mengucapkan terimakasih banyak atas kebaikan hati Saudara Presiden.

Ibid., hlm.98.

30 Sofyan Ibrahim Tiba dalam Kaoy Syah, Ibid., hlm. 98 99. 
Kami mohon (sambil menyodorkan secercik kertas kepada Presiden Soekarno), sudi kiranya Saudara presiden menulis sedikit di atas kertas ini".

Mendengar ucapan Beureu'eh tersebut, langsung Soekarno menangis terisak-isak. Air matanya yang mengalir di pipinya membasahi bajunya. Dalam keadaan terisak-isak tersebut, Soekarno berkata:

"Kakak, kalau begitu tak ada gunanya aku jadi Presiden. Apa gunanya jadi Presiden jika tidak dipercaya". Langsung saja Daud Beureu'eh menjawab "Bukan kami tidak percaya Saudara Presiden, akan tetapi hanya sekedar menjadi tanda yang akan kami perlihatkan kepada rakyat Aceh yang nantinya akan berjuang". Lantas Soekarno sambil menyeka air matanya, berkata: “Wallah Billah, kepada daerah Aceh nanti akan diberikan hak untuk menyusun rumah tangganya sendiri sesuai dengan Syariat Islam. ${ }^{31}$ Wallah, saya akan pergunakan pengaruh saya agar rakyat Aceh benar-benar nanti dapat melaksanakan syari'at Islam dalam daerahnya. ${ }^{32}$ Nah, apakah kakak masih ragu-ragu? dan dijawab oleh Daud Beureu'eh; "Saya tidak ragu lagi Saudara Presiden. ${ }^{33}$ Sekali lagi atas nama rakyat Aceh saya mengucapkan terimakasih atas kebaikan hati Saudara Presiden". ${ }^{34}$

Cuplikan potongan pembicaraan antara Presiden Soekarno dan Daud Beureu'eh selaku Ulama Karismatik Aceh yang juga sebagai Gubernur Militer Aceh pada masa itu memperlihatkan bahwa eksistensi serta peran startegis Ulama di Aceh memiliki dominasi yang sangat kuat dalam setiap sendi-sendi kehidupan masyarakat Aceh masa itu maupun jauh hari sebelumnya. Setelah pertemuan di antara kedua tokoh tersebut, dengan segenap pengaruh dan kharismatik yang dimiliki oleh Daud Beureu'eh telah menyakinkan seluruh rayat Aceh bahwa perang yang sedang dan yang terus dilakukan kedepan oleh rakyat Aceh adalah perang Fii Sabilillah (perang dalam membela agama Allah), maka seluruh rakyat Aceh turut mengambil bagian dalam se-

Ibid.
}

tiap pertempuran melawan imperialisme Belanda bahkan Kerajaan Belanda kehilangan Jenderal Kohler pada pertempuran di seputar lokasi Masjid Raya Baiturrahman (Masjid Bersejarah di Aceh yang terletak di Kuta Raja yang sekarang bernama Kota banda Aceh).

Aceh merupakan satu-satunya daerah di Indonesia yang bebas dari pendudukan Belanda di masa revolusi fisik (1945-1949). Situasi tersebut menyebabkan Aceh dapat dengan leluasa membantu wilayah Sumatara Timur pada front Medan Area. Situasi tersebut juga dimanfaatkan oleh Duta Besar L.N Palar di Perserikatan Bangsa Bangsa (PBB) atau DR. Sudarsono sebagai Diplomat yang menghubungi India untuk menunjukkan kepada dunia internasional bahwa Republik Indonesia dapat bertahan bahkan masih memiliki Aceh yang tetap tegak kokoh tanpa jamahan Kerajaan Belanda sedikitpun yang secara de facto dan de jure memiliki luas dan lebih besar daripada negeri Belanda. ${ }^{35}$

Berkat kontribusi Aceh dalam mempertahankan kemerdekaan sekaligus guna memenuhi janji presiden Soekarno, maka pada tahun 1949atas nama Presiden, Wakil Perdana Menteri menetapkan Peraturan Wakil Perdana Menteri Pengganti Peraturan Pemerintah Nomor 8/Des/ WKPM/1949 tertanggal 17 Desember 1949 tentang Pembentukan Provinsi Aceh, yang dengan itu dinyatakan Aceh sebagai satu provinsi yang berdiri sendiri yang lepas dari Provinsi Sumatera Utara. ${ }^{36}$ Namun akhirnya, setelah Republik Indonesia kembali ke negara kesatuan, melalui Peraturan Pemerintah Pengganti Undang-undang Nomor 5 Tahun 1950 tentang Pembentukan Provinsi SumateraUtara sebagai daerah otonom yang mulai berlaku 15 Agustus 1950, status daerah Aceh kembali ditetapkan menjadi salah satu karesidenan dalam Provinsi Sumatera Utara, selain Sumatera Timur dan Tapanuli. ${ }^{37}$

Ketetapan ini menimbulkan kekecewaan yang mendalam di kalangan pemimpin dan rakyat Aceh, yang pada akhirnya menimbulkan gejolak perlawanan pada bulan September 1953

\footnotetext{
35 Hardi dalam Kaoy Syah, Ibid., hlm. 66.

36 Husni Jalil, 2005, Eksistensi Otonomi Khusus Provinsi Nanggroe Aceh Darussalam Dalam Negara Kesatuan RI Berdasarkan UUD 1945, Bandung: CV. Utomo, hlm. 179.

37 Ibid., hlm. 186.
} 
yang melibatkan hampir seluruh rakyat Aceh dengan label Darul Islam/Tentara Islam Indonesia (DI/TII) yang langsung dipimpin oleh Tgk. M. Daud Beureu'eh.Pada saat dideklarasikan, Aceh disebut sebagai Negara Bagian Aceh dari Negara Islam Indoensia (NBA-NII). Adapun DI/TII dipimpin oleh Sekarmadji Maridjan Kartosuwiryo.

Berdasarkan Status nama pemberontakan Aceh memiliki makna bahwa pemberontakan yang dipimpin oleh Tgk. M. Daud Beureu'eh bukan menjadikan Aceh sebagai negara sendiri terpisah dari Indonesia, melainkan masih sebagai bagian dari Negara Islam Indonesia. Hal ini bermakna bahwa pemberontakan di Aceh masa itu bukan merupakan pemberontakan dalam artian separatis, melainkan bentuk perlawanan terhadap kekuasaan negara yang sah yang telah mengecewakan rakyat Aceh. Dalam situasi tersebut para elit Partai Komunis Indonesia (PKI) turut bermain dalam menyulut kekecewaan rakyat Aceh guna memperlemah rezim Soekarno sebagai upaya percepatan transformasi ideologi komunis ke Republik Indonesia melalui perebutan kekuasaan secara tidak sah (kudeta).

Empat tahun dalam pertikaian antara Pemerintah dengan rakyat Aceh akhirnya membuat Pemerintah menyadari bahwa pemberontakkan Aceh melawan Pemerintah Indonesia memang sia-sia karena harus perang saudara, perang dengan saudar-saudara seiman dan saudara-saudara yang telah memilik andil besar dalam upaya mempertahankan kemerdekaan Indonesia dari imperialisme Belanda ketika masa revolusi fisik. Dalam upaya menampung aspirasi dan tuntutan rakyat Aceh tersebut, Pemerintah menetapkan kembali status Karesidenan Aceh menjadi daerah otonom Provinsi Aceh melalui Undang-Undang Nomor 24 Tahun 1956 tentang Pembentukan Daerah Otonom Provinsi Atjeh dan Perubahan Peraturan Pembentukan Provinsi Sumatra Utara, dimana Ali Hasymy diangkat sebagai Gubernur/Kepala Daerah Aceh berdasarkan ketetapan Presiden No. 615/M/1957 tanggal 5 januari 1957. ${ }^{38}$

38 Husni Jalil, op.cit., hlm. 194.
Perjalanan ketatanegaraan Indonesia memiliki aneka ragam ideologi dan kepentingan telah mendorong Presiden Soekarno mengenabangkan Manifesto politik dengan poros Nasional-Agama dan Komunis (NASAKOM). Melalui konsep NASAKOM inilah selanjutnya memberi ruang kepada ideologi Komunis untuk membentuk Partai dengan nama Partai Komunis Indonesia (PKI) dan turut terlibat dalam penyelenggaraan pemerintahan negara.

Kebijakan politik tersebut menimbulkan penolakan dan reaksi keras dari sebagian besar rakyat di seluruh Indonesia, terutama dari mereka di daerah-daerah yang memiliki basis Islam yang kuat seperti di Sumatra Barat dengan nama Dewan Banteng dipimpin oleh Kolonel Ahmad Husein, di Sumatra Selatan dengan nama Dewan Gajah, di Sulawesi dengan nama Perjuangan Semesta (Permesta). ${ }^{39}$ Pemberontakan semakin meluas melebihi pemberontakan DI/TII di Aceh, yaitu pemberontakan Pemerintah Revolusioner Republik Indonesia (PRRI) dan Perjuangan Semesta (Permesta) yang dipimpin oleh para Panglima Militer di daerah-daerah. Di Sumatra Barat dipimpim oleh Ahmad Husein, di Sumatra dipimpin oleh Sombolon, di Sumatra Selatan dipimpin oleh Barlian dan di Sulawesi dipimpin oleh Kawilarang.

Pemberontakan yang berkepanjangan dan meluas tersebut akhirnya menimbulkan krisis nasional dan instabilitas keamanan nasional. Situasi tersebut yang kemudian membuat Presiden Soekarno menyatakan negara dalam keadaan bahaya (SOB). Dalam upaya mengantisipasi situasi krisis dan pemeliharaan keamanan pada tingkat pusat di bentuk Penguasa Perang Daerah (Peperda) yang dipimpin oleh para Panglima KODAM dengan Gubernur sebagai wakilnya. Upaya lain yang dilakukan oleh Pemerintah menuju penyelesaian masalah keamanan salah satunya di Aceh secara menyeluruh adalah dengan mengirimkan satu misi khusus di bawah pimpinan Wakil Perdana Menteri yang mem-berikan status Daerah Istimewa melalui Keputu-san Perdana Menteri Republik Indonesia Nomor 1/Missi/1959 yang mulai berlaku tanggal

39 Kaoy Syah, op. cit., hlm. $64-65$. 
26 Mai 1959, yang isinya tentang Keistimewaan Provin-si Aceh yang meliputi bidang agama, keistime-waan bidang peradatan, dan keistimewaan bi-dang pendidikan. ${ }^{40}$ Ditinjau dari aspek sejarah, Surat Keputusan Perdana Menteri Republik In-donesia Nomor I/Missi/1959 tersebut merupa-kan tonggak sejarah bagi eksistensi Ulama be-serta dengan perlembagaan ulama di Aceh pas-ka kemerdekaan sekaligus sebagai cikal bakal lahirnya Majelis Permusyawaratan Ulama (MPU) dalam mengisi keistimewaan Aceh dalam bidang agama dan peran ulama dalam penetapan ke-bijakan daerah.

Status keistimewaan Aceh selanjutnya semakin diperkuat dengan hadirnya Undang-Undang Nomor 44 Tahun 1999 tentang Penyelenggaraan Keistimewaan Provinsi Daerah Istimewa Aceh, yang meliputi: penyelenggaraan kehidupan beragama, penyelenggaraan kehidupan adat, penyelenggaraan pendidikan, dan peran ulama dalam penetapan kebijakan Daerah. Secara filosofis, lahirnya Undang-Undang Nomor 44 Tahun 1999 tersebut dalam rangka memberikan landasan bagi Provinsi Daerah Istimewa Aceh dalam mengatur urusan-urusan yang telah menjadi keistimewaannya melalui kebijakan Daerah.

Untuk memperkuat keberadaan penyelenggaraan keistimewaan Aceh dibawah rezim Undang-Undang Nomor 44 Tahun 1999 tentang Penyelenggaraan Keistimewaan Provinsi Daerah Istimewa Aceh sekaligus guna memberi kewenangan yang luas dalam menjalankan pemerintahan bagi Provinsi Daerah Istimewa Aceh, maka disusun kelembagaan Majelis Permusyawaratan Ulama (MPU) Aceh melalui Peraturan Daerah Istimewa Aceh Nomor 3 Tahun 2000 tentang Pembentukan Organisasi dan Tata Kerja Mejelis Permusyawaratan Ulama Provinsi Daerah Istimewa Aceh. Seiring dengan perjalanan waktu yang menghendaki adanya penyesuaian perkembangan dan kebutuhan di lapangan, selanjutnya Peraturan Daerah Istimewa Aceh Nomor 3 Tahun 2000 tersebut dicabut dengan telah disahkan-

40 Darmawan, "Kedudukan Hukum Adat dalam Otonomi Khusus", Jurnal IImu Hukum KANUN, No. 51 Tahun XI Agustus 2010, Aceh: FH UNSIYAH, hlm. 332. nya Qanun Aceh Nomor 2 Tahun 2009 tentang Majelis Permusyawaratan Ulama.

Keberadaan kelembagaan MPU Aceh tersebut merupakan instrument untuk melaksanakan status keistimewaan Aceh dalam bidang peran ulama dalam penetapan kebijakan daerah sebagaimana yang diamanatkan dalam Pasal 3 ayat (2) huruf d Undang-Undang Nomor $44 \mathrm{Ta}$ hun 1999 tentang Penyelenggaraan Keistimewaan Provinsi Daerah Istimewa Aceh. Dalam upaya menyempurnakan pelaksanaan keistimewaan Aceh tersebut maka pada tahun 2001 disahkannya Undang-Undang Nomor 18 Tahun 2001 tentang Otonomi Khusus bagi Provinsi Daerah Istimewa Aceh sebagai Provinsi Nanggroe Aceh Darussalam. Dengan demikian bermakna bahwa Provinsi Aceh selain melekat status istimewa secara bersamaan juga melekat daerah dengan status Otonomi Khusus (Otsus).

Berdasarkan kewenangan otonomi khusus yang diberikan kepada Aceh melalui UndangUndang Nomor 18 Tahun 2001, maka pluralisme penerapan hukum di Aceh pun mulai diakui dan diberlakukan kembali. ${ }^{41}$ Undang-Undang Nomor 18 Tahun 2001 tersebut akhirnya dicabut dan dinyatakan tidak berlaku lagi seiring dengan telah disahkannya Undang-Undang Nomor $11 \mathrm{Ta}$ hun 2006 tentang Pemerintahan Aceh. Kelahiran Undang-Undang Nomor 11 Tahun 2006 merupakan bahagian upaya dari kedua pihak (Pemerintah dan Gerakan Aceh Merdeka) untuk penyelesaian konflik berkepanjangan di Aceh. ${ }^{42}$

Aspek dan Implikasi Yuridis Keberadaan Fatwa MPU Aceh tentang paham atau aliran sesat

Pasal 5 Qanun Aceh No. 2 Tahun 2009 tentang Majelis Permusyawaratan Ulama, mengamanatkan bahwa:

Wewenang Majelis Permusyawaratan Ulama (MPU) Aceh ada dua: (a) menetapkan fatwa terhadap masalah pemerintahan, pembangunan, ekonomi, sosial budaya dan kemasyarakatan; dan (b) memberi-

41 Bakti Siahaan, “Pemberlakuan Syari'at Islam di Aceh Berhadapan Hukum Nasional di Indonesia”,Jurnal Ilmu Hukum KANUN,No. 47 Tahun IX Agustus 2009, Aceh: FH UNSIYAH, hlm. 245.

42 Sulaiman Tripa, "Membentuk Hukum Bagi Perdamaian Aceh", Jurnal Ilmu Hukum KANUN, No. 56 Tahun XIV April 2012, Aceh: FH UNSIYAH, hlm. 159. 
kan arahan terhadap perbedaan pendapat dalam masalah keagamaan baik sesama umat Islam maupun antar umat beragama lainnya.

Berdasarkan rumusan isi Qanun Aceh tersebut sangat jelas bahwa, wewenang menetapkan fatwa bagi(PM) Aceh adalah hanya dalam hal masalah pemerintahan, pembangunan, ekonomi, sosial budaya dan kemasyarakatan. Adapun terkait adanya perbedaan pendapat dalam masalah keagamaan baik sesama umat Islam maupun antar umat beragama, MPU hanya diberikan wewenang untuk memberikan arahan.

Secara yuridis dapat disimpulkan bahwa berdasarkan rumusan Pasal 5 huruf b Qanun Aceh Nomor 2 Tahun 2009 tentang Majelis Permusyawaratan Ulama Aceh, menunjukkan bahwa Fatwa yang telah dikeluarkan oleh MPU Aceh tentang Paham atau Aliran Sesat dan Menyesatkan dalam hal adanya perbedaan pendapat dalam masalah keagamaan diantara para ulama (pimpinan dayah) sebagaimana yang terjadi beberapa kali di Aceh bukan merupakan kewenangan atau otoritas MPU Aceh. Hal ini mengingat, bahwa kewenangan mengeluarkan fatwa dimiliki MPU Aceh hanya dalam hal masalah pemerintahan, pembangunan, ekonomi, sosial budaya dan kemasyarakatan sebagaimana yang diamanatkan Pasal 5 huruf a Qanun Aceh Nomor 2 Tahun 2009. Menyikapi situasi perbedaan pendapat masalah keagamaan diantara ulama (pimpinan dayah/pasantren) di Aceh tersebut, Majelis Permusyawaratan Ulama (MPU) Aceh sepatutnya memberikan arahan sebagaimana yang diamanatkan dalam Pasal 5 huruf $b$ Qanun Aceh Nomor 2 Tahun 2009, bukannya menetapkan/mengeluarkan fatwa.

Argumentasi yang digunakan oleh MPU Aceh yang selama ini menggunakan Qanun Aceh Nomor 11 Tahun 2002 sebagai landasan hukum sebagai dasar justifikasi dalam mengeluarkan fatwa sesat bagi beberapa pimpinan Pasantren/ Dayah di Aceh, secara yuridis MPU Aceh telah melakukan langkah yang sangat keliru. Hal ini mengingat Qanun Aceh Nomor 11 Tahun 2002 tersebut hanya memberikan wewenang kepada MPUAceh untuk menetapkan kriteria-kriteria bentuk-bentuk paham atau aliran sesat sebagaimana yang diamanatkan Pasal 6 Qanun Aceh No. 11 Tahun 2002 tentang Pelaksanaan Syariat Islam Bidang Aqidah, Ibadah dan Syiar Islam mengamanatkan bahwa: "Bentuk-bentuk paham dan atau aliran yang sesat di tetapkan melalui Fatwa MPU", bukannya mengeluarkan/menetapkan fatwa sesat atas kelompok maupun orang tertentu.

Fatwa yang dikeluarkan oleh MPU Aceh yang materi muatannya terkait aliran sesat dan menyesatkan tersebut, secara yuridis telah mengambil peran dan fungsi lembaga yudisial (peradilan) di Aceh dalam hal ini Mahkamah Syar'iyah (MS). Hal ini mengingat MPU Aceh hanya diberi wewenang untuk menetapkan kriteriakriteria bentuk-bentuk paham atau aliran sesat sebagaimana yang diamanatkan Pasal 6 Qanun Aceh Nomor 11 Tahun 2002 tersebut.

Kriteria mengenai bentuk-bentuk paham dan atau aliran sesat yang ditetapkan MPU Aceh tersebut menjadi hukum materill (materiil recht) bagi institusi negara yang berwenang untuk memeriksa, mengadili, dan memutuskan perkara atas dugaan apakah suatu ajaran yang telah disebarkan adalah sesat atau tidak. Adapun Badan atau institusi negara yang berwenang untuk memeriksa, mengadili dan memutuskan/menetapkan perkara terkait dengan dugaan adanya pelanggaran terhadap ketentuanketentuan yang terdapat dalam Qanun Aceh Nomor 11 Tahun 2002 tersebut termasuk menyangkut dugaan adanya penyebaran faham atau aliran sesat adalah Mahkamah Syari'ah sebagaimana yang diamanatkan dalam Pasal 19 Qanun Aceh Nomor 11 Tahun 2002 yang menentukan bahwa pelanggaran terhadap ketentuanketentuan yang terdapat dalam Qanun ini diperiksa dan diputuskan oleh Mahkamah Syariyah. Kalimat "ketentuan-ketentuan dalam qanun ini" termasuk Pasal 5 ayat 2 Qanun Aceh Nomor 11 Tahun 2002 yang menentukan bah-wa setiap orang dilarang menyebarkan faham atau aliran sesat.

Keberadaan beberapa fatwa MPU Aceh tentang aliran sesat dan menyesatkan terkait dengan adanya perbedaan pendapat dalam ma- 
salah keagamaan diantara para pimpinan pesantren/dayah yang terjadi di Aceh tersebut secara nyata menunjukkan bahwa MPU Aceh telah bertindak di luar kewenangannya (kompetensi). sehingga berbagai fatwa sesat dan menyesatkan yang telah dikeluarkan oleh MPU Aceh di beberapa kabupaten di Aceh bertentangan dengan Qanun Aceh Nomor 2 Tahun 2009 tentang Majelis Permusyawaratan Ulama Aceh jo Qanun Aceh Nomor 11 Tahun 2002 tentang Pelaksanaan Syariat Islam Bidang Aqidah, Ibadah dan Syiar Islam. Secara hukum, kondisi ini menimbulkan implikasi yuridis di mana berbagai fatwa yang telah dikeluarkan oleh MPU Aceh terkait dengan Aliran sesat dan menyesatkan tersebut tidak sah dan karenanya batal demi hukum, sehingga karenanya fatwa tersebut tidak dapat dieksekusi.

\section{Penutup}

Simpulan

Pembentukan kelembagaan MPU Aceh melalui Peraturan Daerah Istimewa Aceh Nomor 3 Tahun 2000 tentang Pembentukan Organisasi dan Tata Kerja Mejelis Permusyawaratan Ulama Provinsi Daerah Istimewa Aceh yang selanjutnya dicabut dengan telah disahkannya Qanun Aceh Nomor 2 Tahun 2009 tentang Majelis Permusyawaratan Ulama merupakan instrumen untuk melaksanakan status keistimewaan Aceh dalam bidang peran ulama dalam penetapan kebijakan daerah sebagaimana yang diamanatkan dalam Pasal 3 ayat (2) huruf d Undang-Undang Nomor 44 Tahun 1999 tentang Penyelenggaraan Keistimewaan Provinsi Daerah Istimewa Aceh.

MPU Aceh secara hukum diberi wewenang untuk menetapkan fatwa hanya terhadap masalah pemerintahan, pembangunan, ekonomi, sosial budaya dan kemasyarakatan sebagaimana yang diamanatkan dalam Pasal 5 huruf a Qanun Aceh Nomor 2 Tahun 2009. Selain diberi wewenang untuk menetapkan fatwa, MPU Aceh juga diberi wewenang untuk memberikan arahan dalam menghadapi perbedaan pendapat dalam masalah keagamaan baik sesama umat Islam maupun antar umat beragama lainnya sebagaimana diamanatkan Pasal 5 huruf b Qanun Aceh
Nomor 2 Tahun 2009 tentang Majelis Permusyawaratan Ulama.

MPU Aceh dalam prakteknya dalam hal menyikapi perbedaan pendapat dalam masalah keagamaan diatara para pemimpin pasentren/ dayah di beberapa daerah di Aceh bukannya memberikan arahan sebagaimana yang diamanatkan Pasal 5 huruf b Qanun Aceh Nomor 2 Tahun 2009 melainkan mengeluarkan fatwa. Selain itu fatwa yang dikeluarkan oleh MPU Aceh yang materi muatannya terkait aliran sesat dan menyesatkan, secara yuridis telah mengambil peran dan fungsi lembaga yudisial (peradilan) di Aceh dalam hal ini Mahkamah Syar'iyah (MS). Hal ini MPU Aceh hanya diberi wewenang untuk menetapkan kriteria-kriteria bentuk-bentuk paham atau aliran sesat sebagai-mana yang diamanatkan Pasal 6 Qanun Aceh Nomor 11 Tahun 2002 tentang Pelaksanaan Syariat Islam Bidang Aqidah.

Kriteria mengenai bentuk-bentuk paham dan atau aliran sesat yang ditetapkan MPU Aceh tersebut selanjutnya menjadi hukum materill (materiil recht) bagi institusi negara yang berwenang untuk memeriksa, mengadili, dan memutuskan perkara atas dugaan apakah suatu ajaran yang telah disebarkan adalah sesat atau tidak. Badan atau institusi negara yang berwenang untuk memeriksa, mengadili dan memutuskan perkara terkait dengan dugaan adanya pelanggaran terhadap ketentuan-ketentuan yang terdapat dalam Qanun Aceh Nomor 11 Tahun 2002 tersebut termasuk menyangkut dugaan adanya penyebaran faham atau aliran sesat adalah Mahkamah Syari'ah, sebagaimana yang diamanatkan dalam Pasal 19 Qanun Aceh Nomor 11 Tahun 2002.

Keberadaan beberapa fatwa yang telah dikelaurkan/ditetapkan MPU Aceh tentang aliran sesat dan menyesatkan terkait dengan adanya perbedaan pendapat dalam masalah keagamaan diantara para pimpinan pasantren/dayah yang terjadi di Aceh selama ini secara nyata menunjukkan bahwa MPU Aceh telah bertindak di luar kewenangannya (kompetensi). Hal ini menyebabkan, berbagai fatwa tentang aliran sesat dan menyesatkan tersebut bertentangan dengan Qanun Aceh Nomor 2 Tahun 2009 ten- 
tang Majelis Permusyawaratan Ulama Aceh jo Qanun Aceh Nomor 11 Tahun 2002 tentang Pelaksanaan Syariat Islam Bidang Aqidah, Ibadah dan Syiar Islam. Secara hukum, kondisi ini menimbulkan implikasi yuridis dimana berbagai fatwa yang telah dikeluarkan oleh MPU Aceh terkait dengan Aliran sesat dan menyesatkan tersebut tidak sah dan karenanya batal demi hukum, sehingga karenanya fatwa tersebut tidak dapat dieksekusi.

\section{Daftar Pustaka}

Abidin, Zainal."Pemberlakuan Syari'at Islam sebagai Hukum Positif di Provinsi Aceh". Jurnal Ilmiah Ilmu-ilmu Sosial dan Kemasyarakatan MONDIAL. Vol. 12 No. 21 Januari - Juni 2010. Aceh: UPT. Perpustakaan UNSIYAH;

Basri, Hasan. "Kedudukan Syari'at Islam di Aceh dalam Sistem Hukum Indonesia". Jurnal Ilmu Hukum KANUN. No. 55 Tahun XIII Desember 2011. Aceh: FH UNSIYAH;

Danial dkk,. "Pelaksanaan Syari'at Islam dan Kekerasan di Aceh", Jurnal Kajian Aceh Seumike'. Vol. 3 No. 1 November 2007. Aceh: Aceh Institute Press;

Darmawan. "Kedudukan Hukum Adat dalam Otonomi Khusus".Jurnal Ilmu Hukum KANUN. No. 51 Tahun XII Agustus 2010. Aceh: FH UNSIYAH;

Jalil, Husni, dkk."Implementasi Otonomi Khusus di Provinsi Aceh berdasarkan UndangUndang Nomor 11 Tahun 2006". Jurnal Ilmu Hukum KANUN.No. 51 Tahun XII Agustus 2010. Aceh: FH UNSIYAH;

Jalil, Husni. 2005. Eksistensi Otonomi Khusus Provinsi Nanggroe Aceh Darussalam dalam Negara Kesatuan RI Berdasarkan UUD 1945. Bandung: CV. Utomo;

Kurniawan. "Demokrasi dan Konstitusionalisme Hukum Islam di Indonesia". Jurnal IImu Hukum KANUN. No. 55 Tahun XIII Desember 2011. Aceh: FH UNSIYAH;

-.--.-. "Dinamika Formalisasi Syari'at Islam di Indonesia".Jurnal Ilmu Hukum KANUN. No. 58 Tahun XIV Desember 2012. Aceh: FH UNSIYAH;

"Eksistensi Masyarakat hukum adat dan Lembaga-Lembaga Adat di Aceh dalam Penyelenggaraan Keistimewaan dan Otonomi Khusus di Aceh". Jurnal Hukum
YUSTISIA. Vol. 84 No. 22 September Desember 2012. Surakarta: FH UNS;

Mansur, Teuku, Muttaqin,. Jalil, Faridah."Aspek Hukum Peradilan Adat di Indonesia Periode 1602-2009". Jurnal Ilmu Hukum KANUN. No. 59 Tahun XIV April 2013. Aceh: FH UNSIYAH;

Musa, Malik. "Kewenangan, Peran, dan Tugas Lembaga Tuha Peut di Aceh". Jurnal Hukum dan Keadilan MEDIASI. Vol. 1 No. 2 Mei 2011. Aceh: FH UNMUHA;

Purnama, Eddy. "Refleksi Otonomi Khusus Berdasarkan Undang-Undang Nomor 11 Tahun 2006“.Jurnal Ilmiah Ilmu-ilmu Sosial dan Kemasyarakatan MONDIAL. Vol. 12 No. 21 Januari - Juni 2010. Aceh: UPT. Perpustakaan UNSIYAH;

Siahaan,Bakti.“Pemberlakuan Syari'at Islam di Aceh Berhadapan Hukum Nasional di Indonesia". Jurnal Ilmu Hukum KANUN. No. 47 Tahun IX Agustus 2009. Aceh: FH UNSIYAH;

Sulaiman. "Keadilan Bagi Korban Pelanggaran Berat HAM Masa Lalu di Aceh". Jurnal Hukum dan Keadilan MEDIASI. Vol. 1 No. 3 September 2011. Aceh: FH UNMUHA;

Syah,Kaoy. 2004. Keistimewaan Aceh dalam Lintasan Sejarah. Jakarta: Pengurus Besar Al-Jami'iyatul Washliyah;

Taqwaddin."Kewenangan Mukim dalam Pengelolaan Sumber Daya Alam". Jurnal Ilmu Hukum KANUN. No. 48 Tahun IX Desember 2009. Aceh: FH UNSIYAH;

Tripa, Sulaiman. "Membentuk Hukum bagi Perdamaian Aceh". Jurnal Ilmu Hukum KANUN. No. 56 Tahun XIV April 2012. Aceh: FH UNSIYAH;

Wandita, Galuh. Burgess, Patrick. "Minum Kopi Pahit Asli Aceh: Membuka Jendela-jendela Pertanggungjawaban atas Kekerasan Masa Lalu". Jurnal Kajian Aceh Seumike'. Vol. 4 No. 21 Februari 2009. Aceh: Aceh Institute Press;

Yoesoef, Mohammad, Daud. "Qanun Sebagai Aturan Pelaksana Peraturan PerundangUndangan Atasan". Jurnal Ilmu Hukum KANUN.No. 47 Tahun IX Agustus 2009. Aceh: FH UNSIYAH. 